\title{
Hydraulic Fracking, Shale Energy Development, and Climate Inaction: A New Landscape of Risk in the Trump Era
}

\author{
Anthony E. Ladd' \\ Loyola University New Orleans \\ Richard York \\ University of Oregon
}

\section{Abstract}

With the recent election of Donald J. Trump to the Presidency, fossil fuel interests are poised to advance their entire energy agenda on a number of key fronts. Not only has Trump taken steps to increase oil and gas fracking, create more energy infrastructure projects, ramp up foreign fossil fuel exports, resurrect the Keystone XL and Dakota Access pipelines, and bring back coal production to Appalachian communities, but he has also worked to dismantle most of the signature policies of the Obama administration to fight the effects of climate change. More importantly, he has surrounded himself with cabinet members and advisors who are not just indifferent to environmental problems, but openly hostile to their remediation through government regulations and policy-making. In this critical essay, we draw on sociological research to highlight some of the ongoing technological risks and socio-environmental impacts surrounding unconventional gas and oil development (UGOD) and high-volume hydraulic fracturing (HVHF) operations. We briefly address how these hazards are likely to be exacerbated by the policies and cabinet appointments of the Trump administration — as well as the larger congressional Republican energy and environmental agenda-over the coming months. Finally, we conclude with some observations on the future direction of US energy policy in the Trump era and the amplified risks posed by the prospects of a new Third Carbon era driven by fracking and other methods of unconventional energy production.

Keywords: hydraulic fracturing, fracking, shale energy, unconventional oil and gas development, energy policy in the Trump administration

1 Corresponding author: aladd@loyno.edu 


\section{Introduction}

One of the first executive actions of Republican President Ronald Reagan after taking office in January of 1981 was to order the dismantling of the 32 solar energy panels that his predecessor, President Jimmy Carter, had installed on the roof of the White House in 1979 . The move was intended to signal not only a sharp ideological departure from the energy policies of the Carter administration, but the beginning of a full-scale political backlash against the role of the federal government in regulating environmental pollution. History repeated itself on 20 January 2017, when newly elected Republican President Donald Trump, as one of his first executive actions, ordered the removal of the policy page on climate change issues that his predecessor, President Barack Obama, had ordered published on the White House website during his second term (Parker, 2017). In its place was the Trump administration's new "America First Energy Plan," a short and strident declaration calling for an end to the "burdensome regulations on our energy industry" and the elimination of "harmful and unnecessary policies such as the Climate Action Plan and the Waters of the U.S. rule." More specifically, the Trump energy plan vowed to "embrace the shale oil and gas revolution" by taking advantage of the "estimated $\$ 50$ trillion in untapped shale oil and natural gas reserves, especially on those federal lands that the American people own" (White House, 2017). Nowhere in the document are any references made to the controversial technological practices that will be used to extract these energy deposits from deep beneath the surface of the ground and oceans, nor any mention of the potential social or environmental costs associated with the invasive industrial techniques-more commonly known as hydraulic "fracking"-required for shale energy development (Bamberger \& Oswald, 2014; Finkel, 2015).

The controversy over unconventional gas and oil development (UGOD) and highvolume hydraulic fracturing $(\mathrm{HVHF})$ represents one of the most contentious arenas of social and environmental conflict in the US today (Bamberger \& Oswald, 2014; Crowe et al., 2015; Evensen et al., 2014; Gullion, 2015; Hauter, 2016; Ladd, 2013, 2014, 2017; Malin \& DeMaster, 2016; Wilber, 2015). Proponents trumpet fracking as an economic "game changer" that creates jobs, personal wealth, tax revenues, rural revitalization, and energy independence from foreign oil. Other supporters, including some environmental groups, view natural gas fracking as providing a cleaner "bridge fuel" to a renewable energy future that will lower carbon emissions, as well as reduce the planetary risks posed by climate change (Cosgrove et al., 2015; Gold, 2014; Wright, 2012; Yergin, 2011). While these discursive claims have been challenged (Ladd, 2016; Ladd \& Perrow, 2016), they represent some of the key hegemonic narratives that the fossil fuel industry and its allies have advanced over the past decade to legitimate the socio-environmental risks and profits associated with UGOD/HVHF. For opponents, however, fracking represents myriad threats 
to water quality, aquifers, public health, rural landscapes, roads, property values, animals, farm communities, and nature-based tourism, among other problems (Eaton \& Kinchy, 2016; Finkel, 2015; Ladd, 2017). "Fractivists" and other environmental advocates view gas and oil fracking as not just another risky and inefficient energy source that keeps the nation chained to the fossil fuel treadmill driving climate change, but a dangerous and unregulated technological process that is linked to "every part of the environmental crisis, from radiation exposure to habitat loss" (Steingraber, 2012, p. 175).

As a result of the rapid development of fracking technology and its ancillary infrastructure-well pads, access roads, pipelines, compressor stations, wastewater processing, export facilities, and more-shale gas and oil production has risen $12-$ fold since 2005. During President Obama's two terms in office from 2009-16, over 80,000 new shale wells were drilled and fracked as a cornerstone of his administration's "all of the above" energy policy. As a result, the US is projected to be a net exporter of natural gas, and perhaps the world's largest gas and oil producer, by as early as 2020 (Boudet et al., 2016; Ladd, 2016). Furthermore, the US Energy Information Administration (EIA) has estimated that some additional 630,000 new onshore wells may be required to extract all the technically recoverable reserves of oil and gas beneath the nation's landscape (Hauter, 2016, p. 7). Presently, over 15 million Americans live within a mile of a fracked oil or gas well (Gold, 2014).

Given the boom-bust cycles of resource extraction and the Treadmill of Production contradictions associated with oil and gas development (Freudenburg \& Gramling, 1993; O'Conner, 1994; Schnaiberg, 1980), many observers have called attention to what is perhaps the major economic paradox of the fracking frenzy today-that is, the extent to which the boom in exploration, drilling, and shale extraction has resulted in a short-term oversupply of oil and gas, as well as lower prices in the marketplace (Christopherson, 2015). With the recent election of Donald J. Trump to the Presidency, however, fossil fuel interests now see a chance to advance their entire energy agenda on a number of key fronts. Throughout the 2016 Presidential campaign, Trump vowed to unnerve and undermine the prevailing "liberal elites" of Washington ("Draining the Swamp"), and is moving rapidly to deliver on that pledge. Not only has Trump vowed to increase oil and gas fracking, create more energy infrastructure projects, ramp up foreign fossil fuel exports, resurrect the Keystone XL and Dakota Access pipelines, bring coal production back to Appalachian communities, and revitalize the dormant nuclear power industry, but also dismantle most of the signature policies of the Obama administration to support renewable energy and fight the effects of climate change (Fountain \& Goode, 2016). The number of active drilling rigs in the US has been rising since the election and the Interior Department is considering opening up public lands around some two dozen national monuments to drilling, coal mining, or other development (Bias, 2017). More importantly, Trump has surrounded himself with cabinet members 
and advisors who are not just indifferent to environmental problems, but openly hostile to their remediation through government regulations and policy-making. Indeed, not since the Reagan years of the 1980s and the Bush years of the early 2000s has the hydrocarbon and petrochemical interests of the Energy-Industrial Complex had a potentially greater political ally in the White House.

Assessing the consequences of shale energy development and hydraulic fracking are issues of critical importance for environmental sociology, particularly given its prominent focus on technological risk, social impacts, and the role of energy resources in societal-environmental interactions (Dunlap, 2015). In recent years, the field has generated an impressive research literature that helps situate fracking in the context of other energy-related controversies, including nuclear power (Perrow, 1999), uranium mining (Malin, 2015), oil spills (Ritchie et al., 2012), drilling rig disasters (Freudenburg \& Gramling, 2011), coal production and mountain top removal mining (Bell \& York, 2010, 2012), as well as anthropogenic climate change (Dunlap \& Brulle, 2015).

In this critical essay, we draw extensively on sociological research to highlight some of the ongoing technological risks and socio-environmental impacts surrounding UGOD and HVHF operations. We then turn to a preliminary discussion of how these existing threats and environmental inequalities are likely to be exacerbated by the policies and prospective cabinet appointments of the Trump administration-as well as the larger congressional Republican energy and environmental agenda—over the coming months. Finally, we conclude with some observations on the future direction of US energy policy in the Trump era and the inherent risks posed by the prospects of a new Third Carbon era driven by fracking and other methods of unconventional energy production.

\section{Fractured communities: Risks and impacts associated with unconventional gas and oil fracking}

Patented in the late 1940s by Haliburton but only commercially viable on a broad scale for little more than a decade, hydraulic fracking refers to a controversial well stimulation and completion technique where millions of gallons of water, sand, and chemicals (many of which are toxic) are injected under extreme pressures into deep underground shale deposits to fracture non-porous source rock formations and release the trapped natural gas or oil to the surface (Cable, 2012; Ladd, 2013, 2014). Combined with innovations in seismic mapping and multidirectional drilling, fracking has allowed for dramatic increases in the amount of oil and natural 
gas that can be extracted from previously inaccessible shale formations. These technical processes have been aided by the confluence of assorted laws, subsidies, and infrastructural developments to increase energy production (Hauter, 2016).

The multiple technological risks and impacts associated with UGOD have raised serious concerns among citizens, elected officials, and scientists alike; over 450 community bans against fracking have been passed in 24 states, including cities like Pittsburgh, and statewide moratoriums are in effect in New York, Vermont, and Maryland (Klein, 2014). To date, nearly 700 peer-reviewed publications have provided empirical evidence of the environmental, health, and social consequences of the fracking boom taking place in over a dozen US shale regions (Finkel \& Law, 2016; Ladd, 2017). Potential and known health impacts occur at every stage of UGOD, including emission of air pollutants such as hydrogen sulfide, nitrogen oxides, volatile organic compounds, particulate matter, sulfur dioxide, and ground level ozone from well venting, flaring, heavy truck exhaust, and diesel powered generators (Paulson \& Tinney, 2015). In particular, citizen concerns over fracking have revolved around its potential to contaminate local ground and surface waters through methane migration, fracking fluids, wastewater injection, radioactive gases, carcinogenic compounds, corrosive salts, or radioactive elements like cesium and uranium. Fracking fluids, for example, typically include friction reducers, surfactants, gelling agents, scale inhibitors, acids, corrosion inhibitors, antibacterial agents, and clay stabilizers, among other hazardous compounds, and are known to pose threats to plants, fish, aquatic life, and land animals (Gullion, 2015). Research has also shown exposure to fracking fluids to be associated with cancer, reproductive disruptions, skin, eye, and respiratory symptoms, impairments of the brain and nervous system, gastrointestinal and liver disease, as well as psychosocial stress (Finkel \& Law, 2016; Sangaramoorthy et al., 2016).

One of the most contentious issues surrounding fracking comes from the serious groundwater contamination risks posed by the underground disposal of its wastewaters through deepwell injection methods. Typically, between 15-80\% of the water used in fracking operations is forced back up to the surface of the well each time it is fracked-which can be up to a dozen times over the life of a well. In the US, 2.4 billion gallons of wastewater are injected daily under high pressure into any of the 187,570 disposal wells that accept oil and gas waste across the country. It is difficult to track the disposal of what the industry calls "produced water," which can contain over 300 toxic or hazardous compounds, including salt brines, heavy metals, radioactive materials, hydrocarbons, and volatile organic compounds such as benzene, toluene, ethylbenzene, xylenes, and hydrogen sulfide (Finkel, 2015; Gullion, 2015; Heinberg, 2013; Johnston et al., 2016). Moreover, wastewater injection has also been directly associated with increased seismic activity and more than a thousand earthquakes in such states as Oklahoma, Texas, Colorado, Kansas, and Ohio (Raynes et al., 2016). 
Beyond concerns over water quality, issues of water quantity have been viewed by local residents and officials as key impacts associated with UGOD, particularly the drawing down of local aquifers, surface waters, or public water systems to provide the roughly 2-7 million gallons of water required for each fracking episode (Ladd, 2013). With so many western states like California often experiencing severe drought conditions and declining water availability due to climate change and related weather events, many critics have assailed the oil and gas industry for its enormous consumption of the scarce water resources needed for drinking, farming, and other daily tasks (Hauter, 2016; Kinchy et al., 2015).

One of the major challenges for understanding the environmental and public health threats from fracking is the tangle of laws that inhibits public visibility and research on these issues. Despite regulations in most states requiring the disclosure of various industrial chemicals, the so-called "Haliburton Loophole" (lobbied for by then-Vice President and former Haliburton CEO Dick Cheney) allows oil and gas operators to claim that their fracking additives are "proprietary secrets" that are exempted from reporting under the Safe Drinking Water Act (SDWA). Given too that UGOD is exempt from other federal provisions of the Clean Water Act (CWA), Clean Air Act (CAA), Solid Waste Disposal Act (SWDA), Resource Conservation and Recovery Act (RCRA), Comprehensive Environmental Response, Compensation, and Liability Act (CERCLA), Emergency Planning and Community Right to Know Act (EPCRA), the National Environmental Policy Act (NEPA), as well as several Environmental Protection Agency (EPA) regulations related to hazardous waste disposal, the degree of water and soil contamination caused by fracking is largely unknown to the public (Heinberg, 2013; Kreuze et al., 2016).

Other key impacts of shale development include increased chemical spills, noise, dust, light pollution, road damage, auto accidents, and transportation congestion associated with the increased daily traffic of the hundreds of heavy diesel trucks used to transport the required water, chemicals, sand, drilling equipment, and other production components to rural well sites (Heinberg, 2013; Ladd, 2014; Perrow, 2015; Theodori, 2013; Wilber, 2015). Indeed, fracking has drawn extensive criticism because of its greater social impacts than those incurred through conventional methods of energy development-particularly those related to the industrialization of rural areas, cost of living increases, differential economic benefits from signing royalties and leasing contracts, tensions between surface and mineral rights owners, increases in transient workers, crime, prostitution, rape, substance abuse, housing shortages, psychosocial stress, and diminished social capital (Brasier et al., 2011; Ellis et al., 2016; Hauter, 2016; Malin \& DeMaster, 2016; Sangaramoorthy et al., 2016; Willow, 2014). Finally, other recent research suggests that natural gas fracking is not a "climate-friendly alternative" to coal and oil that will reduce our overall greenhouse gas footprint, nor will it help avert the growing threat of global warming and climate change that its advocates claim. When the expected growth (over 
$150 \%$ ) of methane emissions from shale gas production is factored in over the next two decades, combined with the average methane loss/leakage to the environment that occurs with all US natural gas production (6-12\%), the overall hidden climate footprint of shale gas fracking is arguably worse than coal or oil over its well-toconsumer life cycle (Hauter, 2016; Ladd, 2016).

In sum, the fracking of a shale region's biophysical landscape for oil and gas development inherently creates a system of differential socio-environmental impacts for local stakeholder groups and residents. Depending on how these impacts are experienced over time, place, and audience, mediated by conflicting discursive frames of assorted institutional and residential voices, these synergistic forces can produce the fracturing of a community's ecosystem, sense of place, and social fabric, as well as its patterns of political mobilization and democratic governance (Ladd, 2017). Given the serious risks associated with UGOD and fracking cited in the sociological/social scientific literature, we briefly address how these hazards are likely to be exacerbated by the policies and cabinet appointments of the Trump administration, as well as the larger congressional Republican energy and environmental agenda, over the coming months.

\section{A new landscape of risk}

While environmental disputes over UGOD have been growing since the release of Josh Fox's documentary Gasland in 2010 (Vasi et al., 2015), opposition to fracking did not emerge as a national campaign issue until the 2016 Democratic Presidential race between Bernie Sanders and Hillary Clinton. During a primary debate in Flint, Michigan, Sanders pledged to oppose fracking, while Clinton said she would be in opposition only if a locality or state were against it, releases of methane or water contamination were present, or fracking operators refused to report what chemicals they were using (Leber, 2016). Clinton's stance signified a significant departure from her previous enthusiastic support for natural gas fracking as part of the Obama administration's mixed resource use policies for maximizing domestic energy production and maintaining the fossil fuel treadmill.

On the day before the Democratic National Convention, 10,000 citizens and activists-including tribal members from a number of prominent western indigenous nations-mobilized in Philadelphia to support the "March for a Clean Energy Revolution" through the streets of the city. The protest march called on political leaders to support a national ban on fracking, keep fossil fuels in the ground, ensure environmental justice for all, and work for a quick and lasting transition to a $100 \%$ clean energy economy (Ladd, 2017). While the march did not persuade 
the Democratic Party to endorse a moratorium on fracking, the party platform did call for a greater reliance on clean energy sources and support for the COP 21 Paris Climate Accord, among other measures.

Laying the groundwork for the November election, however, the party platform, passed at the Republican National Convention in Cleveland, took aim at "environmental extremists," called the environmental movement "a self-serving elite," and promised to move responsibility for environmental regulation from "the federal bureaucracy" - particularly the EPA — to the states where few fiscal resources and commitments to government oversight exist (Mufson, 2016). Indeed, the Republican energy plank, emphasizing climate change denial, industry deregulation, and increased fossil fuel production, played a prominent role in motivating Donald Trump's political base to turn out for the Presidential election in states like Louisiana and Texas (Hochschild, 2016).

With the Republican Party now in control of the executive and congressional branches of government, as well as federal judicial appointments and the majority of state governments, Americans are already witnessing a wholesale abandonment of the bipartisan energy policies and regulatory regimes that have been in place since the 1970s. Trump's inner circle on environment and energy issues, including Secretary of State Rex Tillerson, (former ExxonMobil CEO), Secretary of Interior Ryan Zinke (former Montana Congressman), Secretary of Energy Rick Perry (former Texas Governor), Secretary of Agriculture Sonny Perdue (former Georgia Governor), and most importantly, Administrator of the Environmental Protection Agency Scott Pruitt (former Attorney General of Oklahoma), all represent longtime climate change deniers and fossil fuel industry advocates, as well as steadfast opponents of international environmental accords like the Paris climate agreement, federal protections for public lands, or independent scientific research that addresses atmospheric or ecological threats. Indeed, Myron Ebell (Director of a Washington, DC libertarian advocacy group financed by the coal industry), who was chosen by Trump to lead the administration's transition team at the EPA, called the environmental movement "the greatest threat to freedom and prosperity in the modern world" (Rauber, 2017a: 21). Since taking office at the EPA, Scott Pruitt (who as the Oklahoma Attorney General sued the EPA over a dozen times on behalf of state industries fighting to evade federal environmental regulations) has worked to unwind several Obama administration-era climate policies, moved to kill or delay regulations limiting toxic air emissions and water pollution from coal-fired power plants, advocated repeal of the Clean Water Rule, and supported a rollback of regulations to prevent groundwater contamination and methane releases from hydraulic fracking (Rauber, 2017b). Summing up the new Trump regime in Washington, the New York Times observed that, "Across the federal government, lobbyists and lawyers who once battled regulations on behalf of business are now helping run the agencies they once clashed with" (Tabuchi \& Lipton, 2017, p. 1). 
As of September 2017, the Trump administration is rapidly advancing an agenda that represents a virtual carbon copy of the wish list of the fossil fuel industry, including:

- constructing the Keystone XL and Dakota Access pipelines, as well as dozens of oil and gas export facilities in North American coastal communities

- abandoning the COP 21 Paris Climate Agreement

- reducing/blocking funding for the EPA, National Oceanic and Atmospheric Administration (NOAA), and climate research at the National Aeronautics and Space Administration (NASA)_alongside extensive staff cuts

- scrapping the Clean Power Plan

- rescinding the Obama administration's ban on drilling in the Alaskan Arctic, as well as regulations to limit methane leaks from wells and pipelines

- increasing drilling and fracking on public lands and national monuments

- increasing coal production and "clean-coal" technology.

Clearly, these proposed carbon-intensive policies cannot be understood in isolation from the neoliberal deregulatory trends of the past three decades, nor detached from the surge of campaign money unleashed by Citizens United into the coffers of Congressional representatives in key energy states (Perrow, 2015). The enactment of the larger Republican environmental agenda will mean an expansion of offshore and arctic drilling, tar sands development, mountaintop removal coal mining, and other risky energy development policies, while rolling back existing federal programs that encourage energy conservation, environmental justice, and scientific research, as well as those that provide tax incentives and credits for solar, wind, and biomass production - all being carried out, ironically, in the name of US "energy independence." After a two-year downturn in oil and gas prices, US production is on the rise again, with the number of US drilling rigs growing from 450 in April 2016 to 602 as of March 2017 (Bias, 2017).

Given the deep ties of his advisors and cabinet officials to hydrocarbon interests, President Trump-who called climate change a Chinese hoax-is currently presiding over what one researcher called "the most anti-science administration in American history" (Proctor, 2016: 4). The President has so far only filled one of 46 vacant science and technology positions in his administration and the Department of Energy has told staff in its climate office not to use phrases like "climate change," "emissions reduction," or "Paris agreement." In fact, one out of four Trump administrative appointees at agencies dealing with environmental regulations has ties to the fossil fuel industry, while half have no experience in the area in which they now work (Rauber, 2017b, p. 21). Joining other protest declarations from dozens of professional and business interests across the nation, over 420 environmental sociologists signed and released a statement in February 2017 denouncing Trump's cabinet picks and anti-climate policies (Hirji, 2017). 
It is axiomatic to environmental sociologists that energy matters-arguably now more than at any time in recent US history. At its roots, the controversy over fracking can be seen as a subset of the larger conflict over the future direction of American (and global) energy policy, as well as the resources, technologies, and industry elites who will shape US political and economic interests well into the twenty-first century. As observers have noted since the Arab oil embargoes of the 1970s, the nation continues to stand at a critical historical crossroads defined by two mutually exclusive and environmentally distinct energy futures. The question remains the same. Will the US fossil fuel industry and its allies be permitted to expand its hegemonic control over an emerging "Third Carbon Era"-a future defined by unconventional fossil fuel dependence, intensive hydraulic fracking for shale deposits deep beneath the earth and oceans, industry deregulation, and the continued control over the energy sector by essentially the same transnational corporations that control the market today? Or will the democratic majority create the political mechanisms necessary to initiate the transition to a clean energy society defined by curtailing energy consumption, replacement of fossil fuels with renewable resources, efficient technologies, and green economic policies over the next two decades (Ladd, 2016)?

As the environmental storm clouds gather over the nation's capitol and beyond, the contested terrain of risk and benefit associated with increased hydrocarbon production and hydraulic fracking will continue to divide the nation like never before, especially in regions with large shale deposits, energy infrastructures, water shortages, and growing populations (Food and Water Watch, 2015; Thetford, 2013). All told, we believe that the study of unconventional shale development offers fertile ground for environmental sociologists and other researchers who want to better understand one of the leading sources of conflict today that is fracturing both the community and the ecosystem on which humans depend.

\section{References}

Bamberger, M., \& Oswald, R. (2014). The real cost of fracking: How America's shale gas boom is threatening our families, pets, and food. Boston: Beacon Press.

Bell, S. E., \& York, R. (2010). Community economic identity: The coal industry and ideological construction in West Virginia. Rural Sociology, 75(1), 111-143. doi.org/10.1111/j.1549-0831.2009.00004.x

Bell, S. E., \& York, R. (2012). Coal, injustice, and environmental destruction: Introduction to the special issue on coal and the environment. Organization \& Environment, 25(4), 359-367. doi.org/10.1177/1086026612468138

Bias, J. (2017, 5 March). Shale oil industry leaner, fitter. The Times-Picayune, A19. 
Boudet, H., Bugden, D., Zanocco C., \& Maibach, E. (2016). The effect of industry activities on public support for "fracking." Environmental Politics, 25(4), 593-612. doi.org/10.1080/09644016.2016.11537710

Brasier, K. J., Filteau, M. R., McLaughlin, D. K., Jacquet, J., Stedman, R. C., Kelsey, T. W., \& Kelsey, S. W. (2011). Residents' perceptions of community and environmental impacts from development of natural gas in the Marcellus Shale: A comparison of Pennsylvania and New York cases. Journal of Rural Social Sciences, 26(1), 32-61.

Cable, S. (2012). Sustainable failures: Environmental policy and democracy in a petrodependent world. Philadelphia, PA: Temple University Press.

Christopherson, S. (2015). Risks beyond the well pad: The economic footprint of shale gas development in the United States. In M. L. Finkel (Ed.), The human and environmental impact of fracking: How fracturing shale for gas affects us and our world (pp. 115-130) Santa Barbara, CA: Praeger.

Cosgrove, B. M., LaFave, D. R., Dissanayake, S. T. M., \& Donihue, M. R. (2015). The economic impact of shale gas development: A natural experiment along the New York/Pennsylvania border. Agricultural and Resource Economics Review, 44(2), 20-39. doi.org/10.1017/S1068280500010200

Crowe, J., Silva, T., Ceresola, R. G., Buday, A., \& Leonard, C. (2015). Differences in public perceptions and leaders' perceptions on hydraulic fracturing and shale development. Sociological Perspectives, 58(3), 441-463. doi.org/ $10.1177 / 0731121414567355$

Dunlap, R. E. (2015). Environmental sociology. In J. Wright (Ed.), International Encyclopedia of the Social \& Behavioral Sciences (2nd ed.) (pp. 79-803). Elsevier. doi.org/10.1016/B978-0-08-097086-8.91030-4

Dunlap, R. E., \& Brulle, R. J. (2015). Climate change and society: Sociological perspectives. New York, NY: Oxford University Press. doi.org/10.1093/ acprof:oso/9780199356102.001.0001

Eaton, E., \& Kinchy, A. J. (2016). Quiet voices in the fracking debate: Ambivalence, nonmobilization, and individual activism in two extractive communities. Energy Research \& Social Science, 20, 22-30. doi.org/10.1016/j.erss.2016.05.005

Ellis, C., Theordori, G. L., Petrzelka, P., Jackson-Smith, D., \& Luloff, A. E. (2016). Unconventional risks; The experience of acute energy development in the Eagle Ford shale. Energy Research \& Social Science, 20, 91-98. doi.org/10.1016/j. erss.2016.05.006 
Evensen, D., Jacquet, J. B., Clarke, C. E., \& Stedman R. C. (2014). What's the "fracking" problem? One word can't say it all. The Extractive Industries and Society, 1, 130-136. doi.org/10.1016/j.exis.2014.06.004

Finkel, M. L. (2015). The human and environmental impact of fracking: How fracturing shale for gas affects us and our world. Santa Barbara CA: Praeger.

Finkel, M. L., \& Law, A. (2016). The rush to drill for natural gas: A five-year update. American Journal of Public Heath, 106(10), 1728-1730. doi.org/10.2105/ AJPH.2016.303398

Food and Water Watch. (2015, 6 December). The Urgent Case for a Ban on Fracking. Retrieved from www.foodandwaterwatch.org/sites/default/files/Urgent\%20Ban \%20on\%20Fracking\%20Report\%20March\%202015.pdf

Fountain, H., \& Goode, E. (2016, 27 November). Trump has several tools for putting the brakes on climate programs. The New York Times, Y22, national section.

Freudenburg, W.R., \& Gramling, R. (1993). Socio-environmental factors and development policy: Understanding opposition and support for offshore oil. Sociological Forum, 8(3), 341-365. doi.org/10.1007/BF01115049

Freudenberg, W.R., \& Gramling, R. (2011). Blowout in the gulf: The BP oil spill disaster and the future of energy in America. Cambridge, MA: MIT Press.

Gold, R. (2014). The boom: How fracking ignited the American energy revolution and changed the world. New York: Simon \& Schuster.

Gullion, J. S. (2015). Fracking the neighborhood: Reluctant activists and natural gas drilling. Cambridge, MA: MIT Press. doi.org/10.7551/ mitpress/9780262029766.001.0001

Hauter, W. (2016). Frackopoly: The battle for the future of energy and the environment. New York: The New Press.

Heinberg, R. (2013). Snake oil: How fracking's false promise of plenty imperils our future. Santa Rosa, CA: Post-Carbon Institute.

Hirji, Zahra. (2017, 3 February). Trump's choices "detrimental to the planet and people," environmental sociologists say. Inside Climate News. Retrieved from insideclimatenews.org.print. 45257

Hochschild, A. R. (2016). Strangers in their own land: Anger and mourning on the American right. New York: The New Press. 
Johnston, J. E., Werder, E., \& Sebastian, D. (2016). Wastewater wells, fracking, and environmental injustice in southern Texas. American Journal of Public Health, 106(3), 550-556. doi.org/10.2105/AJPH.2015.303000

Kinchy, A. J., Parks, S., \& Jalbert, K. (2015). Fractured knowledge: Mapping the gap in public and private water monitoring efforts in areas affected by shale gas development. Environment and Planning C: Government and Policy. doi.org/ $10.1177 / 0263774 X 15614684$

Klein, N. (2014). This changes everything: Capitalism vs. the climate. New York: Simon \& Schuster.

Kreuze, A, Schelly, C., \& Norman, E. (2016). To frack or not to frack: Perceptions of the risks and opportunities of high-volume hydraulic fracturing in the United States. Energy Research \& Social Science. doi.org/10.1016/j.erss.2016.05.010

Ladd, A. E. (2013). Stakeholder perceptions of socioenvironmental impacts from unconventional natural gas development and hydraulic fracturing in the Haynesville shale. Journal of Rural Social Sciences, 28(2), 56-89.

Ladd, A. E. (2014). Environmental disputes and opportunity-threat impacts surrounding natural gas fracking in Louisiana. Social Currents, 1(3), 293-312. doi.org/10.1177/2329496514540132

Ladd, A. E. (2016). Meet the new boss, same as the old boss: The continuing hegemony of fossil fuels and hydraulic fracking in the third carbon era. Humanity and Society, 41(1), 13-36. doi.org/10.1177/0160597616628908

Ladd, A. E. (2017). Fractured communities: Risk, impacts, and protest against hydraulic fracking in U.S. shale regions. New Brunswick, N.J.: Rutgers University Press.

Ladd, A. E., \& Perrow, C. (2016). Institutional dilemmas of hydraulic fracking: Economic bonanza, renewable energy bridge, or gangplank to disaster? Paper presented at the annual American Sociological Association meetings, August 20-24, Seattle, WA.

Leber, R. (2016). Hilary Clinton has a new tune on fracking. Grist Magazine, 6 March. Retrieved from grist.org/politics/hilary-clinton-has-a-new-tune-onfracking/?utm_medium=email\&utm_source=newsletter\&utm_campaign= daily-horizon.

Malin, S.A. (2014). There's no real choice but to sign: Neoliberalization and normalization of hydraulic fracturing on Pennsylvania farmland. Journal of Environmental Studies and Science, 4(1), 17-27. doi.org/10.1007/s13412-013$0115-2$ 
Malin, S.A. (2015). The price of nuclear power: Uranium communities and environmental justice. New Brunswick, NJ: Rutgers University Press.

Malin, S. A., \& DeMaster, K. T. (2016). A devil's bargain: Rural environmental injustices and hydraulic fracturing on Pennsylvania's farms. Journal of Rural Studies, 47, 278-290. doi.org/10.1016/j.jrurstud.2015.12.015

Mufson, S. (2016, 20 July). Energy platform would reverse decades of policy. The Times-Picayune, A9.

O'Conner, J. (1994). Is sustainable capitalism possible? In M. O'Connor (Ed.) Is capitalism sustainable? Political economy and the politics of ecology (pp. 152175). New York: The Guilford Press.

Parker, A. (2017, 20 January). Trump signals changing priorities, revises White House website to remove climate change. The Washington Post. Retrieved from www.chicagotribune.com/news/nationworld/ct-trump-white-house-website20170120-story.html

Paulson, J. A., \& Tinney, V. (2015). Potential and known health impacts associated with unconventional natural gas extraction. In M. L. Finkel (Ed.), The human and environmental impact of fracking; How fracturing shale for gas affects us and our world (pp. 1-21). Santa Barbara, CA: Praeger.

Perrow, C. (1999). Normal accidents: Living with high risk technologies. (2nd ed.) Princeton, NJ: Princeton University Press.

Perrow, C. (2015). Cracks in the regulatory state. Social Currents, 2(3), 203-212. doi.org/10.1177/2329496515589855

Proctor, R. N. (2016, 20 November). Climate change in the age of ignorance. The New York Times, 4.

Rauber, P. (2017a). The wrecking crew arrives in Washington. Sierra, May/June, $102(3), 21$.

Rauber, P. (2017b). Sharpening the knives. Sierra, July/August, 102(4), 21.

Ritchie, L. A., Gill, D. A., \& Farnham, C. N. (2012). Recreancy revisited: Beliefs about institutional failure following the Exxon Valdez oil spill. Society \& Natural Resources, 26(6), 655-671. dx.doi.org/10.1080/08941920.2012.690066

Raynes, D. K. T., Mix, T. L., Spotts, A., \& Ross, A. (2016). An emotional landscape of place-based activism: Exploring the dynamics of place and emotion in antifracking actions. Humanity \& Society, 40(4), 401-423. doi.org/ $10.1177 / 0160597616669757$ 
Sangaramoorthy, T., Jamison, A. M., Boyle, M. D., Payne-Sturges, D. C., Sapkota, A., Milton, D. M., \& Wilson, S. M. (2016). Place-based perceptions of the impacts of fracking along the Marcellus Shale. Social Science \& Medicine, 151, 27-37. doi.org/10.1016/j.socscimed.2016.01.002

Schnaiberg, A. (1980). The environment: From surplus to scarcity. New York: Oxford University Press.

Steingraber, S. (2012). The Whole Fracking Enchilada. In T. Butler, Lerch, D., \& Wuerthner, G. (Eds.), The energy reader: Overdevelopment and the delusion of endless growth (pp. 175-178). Santa Rosa, CA: Post Carbon Institute.

Tabuchi, H., \& Lipton, E. (2017). Pruitt's E.P.A. is boon to oil and gas. The New York Times, 4 June, 1, national section.

Theodori, G. (2013). Perception of the natural gas industry and engagement in individual civic actions. Journal of Rural Social Sciences, 28(3), 122-134.

Thetford, K. (2013). The natural gas boom: Processes, production, and problems. The Atlantic, 26 August. Retrieved from www.theatlantic.com/technology/ print/2013/08/the-natural-boom-processes-production-and-problems/278913

Vasi, I. B., Walker, E.T., Johnson, J. S., \& Tan, H. F. (2015). No fracking way! Documentary film, discursive opportunity, and local opposition against hydraulic fracturing in the United States, 2010-2013. American Sociological Review, 80(5), 934-959. doi.org/10.1177/0003122415598534

White House. (2017). An America first energy plan. Retrieved from www.whitehouse.gov/america-first-energy

Wilber, T. (2015). Under the surface: Fracking, fortunes, and the fate of the Marcellus shale. Ithaca, NY: Cornell University Press.

Willow, A. J. (2014). The new politics of environmental degradation: Un/expected landscapes of disempowerment and vulnerability. Journal of Political Ecology, 21(1), 237-257.

Wright, S. (2012, 12 July). An unconventional bonanza. The Economist, 3-15.

Yergin, D. (2011). The quest: Energy, security, and the remaking of the modern world. New York: Penguin Press.

York, R. (2015). How much can we expect the rise in U.S. domestic energy production to suppress net energy imports? Social Currents, 2(3), 222-230. doi.org/10.1177/2329496515589850 
This text is taken from Human Ecology Review, Volume 23, Number 1, 2017, published 2017 by ANU Press, The Australian National University, Canberra, Australia.

dx.doi.org/10.22459/HER.23.01.2017.04 